INTERNATIONAL JOURNAL OF MULTIDISCIPLINARY RESEARCh AND ANALySis

ISSN(print): 2643-9840, ISSN(online): 2643-9875

Volume 04 Issue 11 November 2021

DOI: 10.47191/ijmra/v4-i11-02, Impact Factor: 6.072

Page No.- 1509-1512

\title{
Construction of Mathematical Models of Clinical and Immunologi- cal Prognosis of the Severity of Covid-19 in the Population of Uzbekistan
}

\author{
Nodir Fazliddinovich Ruzimurodov ${ }^{1}$, Tamara Uktamovna Aripova ${ }^{2}$ \\ ${ }^{1}$ Junior Researcher, Institute of Immunology and human genomics of the Academy of Science of the Repulic of Uzbekistan, \\ https://orcid.org/0000-0002-5194-1113 \\ ${ }^{2}$ Academican, Director of the Institute of Immunology and human genomics of the Academy of Science of the Republic of Uzbek- \\ istan
}

ABSTRACT: New Coronavirus Infection (COVID-19) is a novel zooanthroponous respiratory infection caused by the Sars-Cov-2 coronavirus. The virus was first identified during an epidemic outbreak in Wuhan City, Hubei Province, China, which has been reported since December 11, 2019. Since then, scientists have been studying the characteristics of the virus to determine the severity of the disease. For a complete and reliable assessment of the severity of the disease in this pathology, the cytokine status was studied and investigated integral characteristics of the clinical and immunological prognosis of the severity of COVID-19 in the population of Uzbekistan.

To assess the study of the cytokine profile in patients with COVID-19, depending on the severity of the disease, an enzyme-linked immunosorbent assay was used and calculated on an IBM Pentium-type personal computer using the "STATISTICA10 " statistical software package.

It was found that, depending on the severity of the disease, patients with COVID-19 have a pronounced cytokine imbalance. The high level of the studied cytokines is a reflection of the activity and severity of the pathological process. The results obtained indicate the activation of the expression of proinflammatory cytokines, for example, IL-1 $\beta$, IL-2, IL-6, TNF- $\alpha$.

The results obtained can be used as a prognostic criterion for the severity of the course and outcome of the disease.

KEYWORDS: COVID-19, coronavirus, cytokine profile, MATHEMATICAL MODELS, CIP-COV.exe.

\section{BACKGROUND}

Coronavirus infection in humans occurs as an acute illness of the respiratory tract with a polymorphic clinical picture. The new coronavirus was identified in early January 2020, initially dubbed 2019-nCoV. It is believed that the virus enters the cell by attachment to receptors angiotensin-converting enzyme 2 (ACE2) using the surface $S$ (spike) protein (4). Clinical transmission transmission of SARS-CoV-2 from symptomatic individuals. Epidemiological and virological studies show that transmission of infection occurs mainly from patients with a clinically expressed disease to other people through close contact by airborne droplets, through direct contact with an infected person or through contact with contaminated objects and surfaces (7).

A characteristic feature of infections caused by SARS-CoV-2 is a pronounced inflammatory reaction in the lung tissue, a reflection of which is a "cytokine storm", i.e. release of large amounts of cytokines in the blood (2). The kinetics of the response to SARS-CoV-2 is consistent with models of induction of conventional antiviral immunity and with a crisis that correlates with the likely phase of the peak of the T-cell response (8). However, reports of increased levels of thrombus formation and endothelial cell death in patients with COVID-19 indicate vascular endothelial damage and the involvement of cytokines and immunothrombosis (3).

Despite numerous studies posted on bioRxiv and medRxiv on elevated levels of cytokines in severe patients with COVID-19, unambiguous information and prognosis for standard treatment tactics are still not available (1).

The progress of clinical medicine to a certain extent depends on the level of diagnosis, prognosis and treatment of patients. The last decades have been characterized by a rapid growth in the number of diagnostic methods, the introduction of the latest electronic equipment, which makes it possible to identify the subtle mechanisms of the pathological process (5). 


\section{Construction of Mathematical Models of Clinical and Immunological Prognosis of the Severity of Covid-19 in the Population of Uzbekistan}

The aim of the work was to develop integral characteristics of the clinical and immunological prognosis of the severity of COVID-19 in the population of Uzbekistan.

\section{MATERIALS AND METHODS}

To solve this problem, a data set of 141 patients with a diagnosis of Covid-19 of varying degrees of course was used. To enter the initial information into a computer for the purpose of its subsequent statistical processing, a special coding card was developed for examining patients, which included 11 clinical indicators related to the outcome and course of the disease.

The patients were divided into several groups:

1) Control group (32 patients);

2) A group of patients with a moderate course (80 patients);

3) A group of patients with severe course (29 patients).

The construction of a mathematical model was carried out using the least squares method in the form:

$$
\Psi(x)=\sum_{i=1}^{n} a_{i} x_{i}+a_{0}
$$

where, $\Psi(x)$ - the severity of the pathological process;

$$
\begin{aligned}
& a_{i}-\text { weighting coefficients of features; } \\
& x_{i}-\text { clinical and immunological parameters; } \\
& a_{0}-\text { free member. }
\end{aligned}
$$

The construction of a mathematical model was carried out taking into account the following minimization criterion:

$$
E[\Psi(x)-S]^{2} \rightarrow \min
$$

where: $E$ - expectation operator;

$S$ - expert assessment of the severity of the pathological process.

The choice of the least squares method was due to the fact that in the study of medical processes, we are dealing with statistical data. That is why statistical data processing is carried out in almost every medical problem and serves as one of the stages of information processing.

Regression analysis is used to identify patterns, that is, to build mathematical models. And here the least squares method is widely used, which is the basic method of regression analysis.

The least squares method has been comprehensively studied and has several theoretical justifications. The LSM estimates have the minimum possible variance in the class of all linear unbiased estimates and are, respectively, the best linear unbiased estimates of the unknown parameters of the function $(5,6)$.

When constructing models of the severity and outcome of the disease by the least squares method, the condition of their effectiveness not lower than $p<0.05$ by the t-test was imposed on the parameters of the model.

As a result of calculations, models of the following type were obtained:

Immunological index $(R \mathbf{2}=\mathbf{0 , 6 8})$

Im $=-0,2814+0,0307 * I 1+0,1023 * I 2+0,0061 * I 3+0,0062 * I 5$

Coagulogram index $(\mathbf{R 2}=\mathbf{0 , 5 9})$

$\mathrm{Kg}=-2,2719+0,0072 * \mathrm{~K} 1-5,1151 * \mathrm{~K} 2+0,0071 * \mathrm{~K} 4$

Complete blood count index $(R \mathbf{2}=\mathbf{0 , 7 8})$

$\mathrm{CBC}=2,8406-0,0104 * A 1+0,0715 * A 6+0,721 * A 8-0,6918 * A 10$ (5)

Physical index $(R 2=0,78)$

Phy $=-3,5042+0,1321 * F 1-0,0361 * F 2+0,1434 * F 3$

Complex (generalized) index $(\mathbf{R 2}=\mathbf{0 , 9 1})$

0,68 Komp $=3,094+0,0024 * 13+0,0026 * 15+0,0025 * K 1-1,8171 * K 2+$ 
Construction of Mathematical Models of Clinical and Immunological Prognosis of the Severity of Covid-19 in the Population of Uzbekistan

$+0,0018 * K 4-0,0098 * K 6-0,0025 * A 1+0,0363 * A 6-0,2071 * A 7+$

$+0,2575 * A 8+0,8821 * R 1+0,7048 * R 2-0,0278 * F 2$

where:

\begin{tabular}{|l|l|}
\hline I1 & IL-1 $\beta(\mathrm{pg} / \mathrm{ml})$ \\
\hline I2 & IL-2 $(\mathrm{pg} / \mathrm{ml})$ \\
\hline I3 & IL-6 $(\mathrm{pg} / \mathrm{ml})$ \\
\hline I5 & C-reactive protein \\
\hline K1 & D-dimer $(\mathrm{ng} / \mathrm{ml})$ \\
\hline K2 & Procalcitonin $(\mathrm{ng} / \mathrm{ml})$ \\
\hline K4 & Fibrinogen $(\mathrm{mg} / \mathrm{dl})$ \\
\hline K6 & prothrombin index $(\%)$ \\
\hline A1 & Platelets (thousands) \\
\hline A6 & Erythrocyte sedimentation rate \\
\hline A7 & Clotting time min \\
\hline A8 & Clotting time max \\
\hline A10 & clotting time (max+min) $/ 2$ \\
\hline & $\begin{array}{l}\text { unilateral lung injury } \\
\text { R1 }- \text { no } \quad 1 \text { - yes }\end{array}$ \\
\hline R2 & $\begin{array}{l}\text { bilateral lung injury } \\
0 \text { - no } 1 \text { - yes }\end{array}$ \\
\hline F1 & Breathing rate \\
\hline F2 & SpO2 $(\%)$ \\
\hline F3 & Temperature $\left({ }^{0} \mathrm{C}\right)$ \\
\hline
\end{tabular}

In this case, the following gradation was adopted for the severity of the pathology:

0 - norm

1 - mild

2 - medium-heavy

3-severe

The calculations were performed on an IBM Pentium-type personal computer using the "STATISTICA-10" statistical software package.

\section{CONCLUSION}

The high value of the coefficient of determination of equations (3-7) testifies to the high efficiency of the obtained models. This served as the basis for the development on their basis of the software tool "Clinical and immunological prognosis of the severity of COVID-19" (CIP-COV.exe), for which the copyright certificate of the Patent Office of the Republic of Uzbekistan was received No. DGU 12771 dated 20.10.2021

\section{REFERENCES}

1) Bingwen Liua, Min Lic, Zhiguang Zhoua, Xuan Guane, Yufei Xianga, // Can we use interleukin-6 (IL-6) blockade for coronavirus disease 2019 (COVID-19)-induced cytokine release syndrome (CRS)? - Journal of Autoimmunity 111 (2020). https://doi.org/10.1016/j.jaut.2020.102452.

2) Braun, J., Loyal, L., Frentsch, M., Wendisch, D., Georg, P., Kurth, F., Hippenstiel, S., Dingeldey, M., Kruse, B., Fauchere, F., Baysal, E., Mangold, M., Henze, L., Lauster, R., Mall, M.A., Beyer, K., Rohmel, J., Voigt, S., Schmitz, J., Miltenyi, S., Demuth, I., Muller, M.A., Hocke, A., Witzenrath, M., Suttorp, N., Kern, F., Reimer, U., Wenschuh, H., Drosten, C., Corman, V.M., Giesecke-Thiel, C., Sander, L. E., Thiel, A., 2020. SARS-CoV-2-reactive T cells in healthy donors and patients with COVID-19. Nature 2020. https://doi.org/10.1038/s41586-020-2598-9. Jul 29. 
Construction of Mathematical Models of Clinical and Immunological Prognosis of the Severity of Covid-19 in the Population of Uzbekistan

3) Huang C., Wang Y., Li X., Ren L., Zhao J., Hu Y., et al. Clinical features of patients infected with 2019 novel coronavirus in Wuhan, China. Lancet. 2020; 395 (10 223): 497-506., Channappanavar R., Perlman S. Pathogenic human coronavirus infections: causes and consequences of cytokine storm and immunopathology. Semin. Immunopathol. 2017; 39 (5): 529539.

4) Kevin Ita // REVIEW ARTICLE Coronavirus Disease (COVID-19): Current Status and Prospects for Drug and Vaccine Development - Archives of Medical Research - (2020). https://doi.org/10.1016/j.arcmed.2020.09.010.

5) Kremer N.Sh. Probability theory and mathematical statistics: Textbook for universities. - M., UNITY-DANA, 2001

6) Mkhitaryan V.S., Troshin L.I., Adamova E.V., Shevchenko K.K., Bambaeva N.Ya. Probability theory and mathematical statistics / Moscow International Institute of Econometrics, Informatics, Finance and Law. - M., 2002

7) Sallard, E., Lescure, F.X., Yazdanpanah, Y., Mentre, F., Peiffer-Smadja, N., 2020. Type 1 interferons as a potential treatment against COVID-19. Antiviral Res. 178, 104791. Sanchez-Cerrillo, I., Landete, P., Aldave, B., Sanchez-Alonso, S., Sanchez-Azofra, A., Marcos-Jimenez, A., Avalos, E., Alcaraz-Serna, A., de Los Santos, I., Mateu- Albero, T., Esparcia, L., Lopez-Sanz, C., Martinez-Fleta, P., Gabrie, L., Del Campo Guerola, L., Calzada, M.J., Gonzalez-Alvaro, I., Alfranca, A., Sanchez-Madrid, F., Munoz-Calleja, C., Soriano, J.B., Ancochea, J., Martin-Gayo, E., 2020. Differential redistribution of activated monocyte and dendritic cell subsets to the lung associates with severity of COVID-19. medRxiv 2020, 20100925. https://doi.org/10.1101/2020.05.13. May 16.

8) Woelfel R., Corman V.M., Guggemos W., Seilmaier M., Zange S., Mueller M.A., Niemeyer D., Vollmar P., Rothe C., Hoelscher M., Bleicker T., Bruenink S., Schneider J., Ehmann R., Zwirglmaier K., Drosten C., Wendtner C., Clinical presentation and virological assessment of hospitalized cases of coronavirus disease 2019 in a travel-associated transmission cluster, medRxiv, (2020) 2020.2003.2005.20030502. 